\title{
LONG TERM EVALUATION OF MAXILLARY GROWTH AFTER ‘THE NON DENUDED PALATOPLASTY' TECHNIQUE
}

\author{
Prasetyanugraheni Kreshanti ${ }^{1}$, Siti Handayani ${ }^{1}$, Maulina Rachmasari ${ }^{{ }^{*}}$, Julieta Pancawati ${ }^{2}$, Amila Jeni \\ Susanto ${ }^{2}$, Grace Wangge ${ }^{3}$, Alita Indania ${ }^{4}$
}

Universitas Indonesia, Department of Surgery, Division of Plastic Reconstructive and Aesthetic Surgery, RSUPN Cipto Mangunkusumo, Jakarta, Indonesia

Orthodontist, Cleft \& Craniofacial Center RSUPN dr.Cipto Mangunkusumo, Jakarta, Indonesia

Southeast Asian Ministers of Educational Organization - Regional Center for Food and Nutrition (SEAMEO-RECFON)/Pusat Kajian Gizi Regional Unicersitas Indonesia

Background : Conventional Two Flap Palatoplasty technique will produce lateral defects without any periosteal coverage. These denuded lateral defects are prone to contamination and infection. These will result in wound contraction, scar formation and maxillary growth impairment. In 2011, we studied "The Non Denuded Palatoplasty" technique. This technique precipitated the epithelialization process of the lateral defects. Faster epithelialization is expected to decrease wound contraction and good maxillary growth.

Method : This is a case control study to compare the maxillary growth of 2 groups consists of unilateral cleft lip and palate patients repaired with "The Non Denuded Palatoplasty" technique and Conventional Two Flap Palatoplasty. The outcome will be evaluated from cephalometry and the dental cast for each patient is evaluated using GOSLON YARDSTICK method. Data will be analyzed using SPSS version 20.

Result : A total of 4 patients in The Non Denuded Palatoplasty group and 10 in the Conventional Two Flap Palatoplasty. The cephalometric SNA, SNB and ANB point showed Class III skeletal jaw relationship or deficient maxilla. Meanwhile the GOSLON yardstick type III are the most common GOSLON on both group with good inter-ratter reliability $(\mathrm{p}=0.839)$ based on Mann Whitney test. In these study, there was no correlation between cephalometric variables with GOSLON score.

Conclusion: Our results showed that modification (The Non Denuded Palatoplasty) technique made no statistically significant difference to the maxillary growth. However this study has several limitations, one of which being the small sample size due to family, social and other factors that are beyond the control of the investigating team. Also the evaluation was conducted in patients aged 7-9 years, hence the result of this study is not the final outcome.

Keywords: maxillary growth evaluation, cephalometry, Goslon Yardstick, two flap palatoplasty

Latar Belakang: Teknik konvensional two flap palatoplasty akan menimbulkan defek lateral tanpa adanya pelindung periosteum. Defek lateral yang terbuka ini menyebabkan kerentanan terhadap kontaminasi dan infeksi. Hal inilah yang akan menimbulkan kontraksi luka, pembentukan skar dan mengganggu pertumbuhan maxilla.

Tahun 2011, terdapat studi mengenai teknik "The Non Denuded Palatoplasty". Teknik ini meninggalkan sebagian periosteum yang diharapkan dapat mempercepat proses epitelisasi pada defek lateral. Epitelisasi yang lebih cepat diharapkan dapat mengurangi terjadinya kontraksi luka dan mencapai pertumbuhan maksila yang baik.

Metodologi: Studi ini merupakan studi kasus kontrol yang terdiri atas 2 grup membandingkan pertumbuhan maksila pasien dengan celah bibir dan langit-langit unilateral komplit yang dikerjakan dengan teknik conventional "Two Flap Palatoplasty" dan teknik "The Non Denuded Palatoplasty". Hasil pengukuran cephalometri dicatat serta dibuat cetakan gigi untuk tiap pasien kemudian dikategorisasi menggunakan metode GOSLON YARDSTICK. Data yang diperoleh dianalisis dengan SPSS versi 20.

Hasil: Terdapat 4 pasien di kelompok "The Non Denuded Palatoplasty" dan 10 pasien pada teknik konvensional "Two Flap Palatoplasty". Hasil pengukuran cephalometri SNA, SNB dan ANB menunjukkan bahwa kedua grup tersebut masuk dalam golongan maloklusi tipe III (defisiensi maksila). Sementara hasil GOSLON Yardstick memperlihatkan GOSLON tipe III sebagai kelompok yang sering ditemukan bagi kedua grup dengan reliabilitas inter-rater baik $(\mathrm{p}=0.839)$. Pada penelitian ini tidak ditemukan korelasi antara variabel cephalometri dengan skor GOSLON

Kesimpulan: Hasil studi kami menunjukkan bahwa teknik modifikasi "The Non Denuded Palatoplasty" tidak berhubungan secara signifikan terhadap pertumbuhan maksila. Namun penelitian ini memiliki beberapa 


\section{INTRODUCTION}

Abnormal facial and maxillary growth in many patients with repaired complete clefts of the lip and palate was a common finding. However, the cause has not been confirmed. In a previous study, Bishara et al. compared individuals with isolated clefts of the palate to normal. It was found that operated and unoperated cleft had similar cephalometric skeletal relations, yet both groups differed from normal individual in that maxilla and mandible were relatively retruded and the mandibular plane was relatively steep.(1) However, Mars and Houston ${ }^{(2)}$ believed scar tissue contraction after operative intervention is the most important factor causing disturbance of maxillary growth.

The previous prospective study in our institution showed that twenty three patients who were treated with "The Non Denuded Palatoplasty" technique significantly had effect in precipitated epithelialization.(3) In this technique, the authors intend not to elevate all layers of mucoperiosteal flap in order to have a thin periosteal layer on the lateral defect. Faster epithelialization was expected to decrease wound contraction thus reducing scar formation, and in the long run will result in good maxillary growth. Long term maxillary growth of patients treated with this technique need to be evaluated.
Several ways of recording the dental relationship have been reported. Dental cast will be evaluated using the GOSLON Yardstick and lateral cephalometry will be evaluated to measure maxillary growth in this research.

\section{MATERIALS AND METHOD}

The subjects, patients with unilateral complete cleft lip and palate (UCCLP) from the previous study who undergone "The Non Denuded Palatoplasty" technique and Conventional Two Flap Palatoplasty during 2010-2011(3) were contacted for follow up and underwent measurements of cephalometric X-ray and dental cast procedure to evaluate maxillary growth. The dental cast will be assessed by one plastic surgeon and two orthodontists using The GOSLON Yardstick method. The lateral skull x-ray will be measured based on cephalometric measurement, SNA, SNB and ANB of each patient will be collected. The inter-rater reliability will be tested using Intraclass Correlation (ICC) test.

This study was performed with approval from Ethical Committee Faculty of Medicine, Universitas Indonesia. (Approval Number: 678/ UN2.F1/ETIK/2017).

\begin{tabular}{lcc}
\hline & $\begin{array}{c}\text { The non denuded } \\
\text { palatoplasty technique (n=4) }\end{array}$ & $\begin{array}{c}\text { The conventional two flap } \\
\text { palatoplasty (n=10) }\end{array}$ \\
\hline Sex & 4 & 6 \\
- Male & 0 & 4 \\
- Female & & \\
Age (year), median & 4 & 2 \\
$\begin{array}{l}\text { Nutritional Status } \\
\text { - Underweight }\end{array}$ & 0 & 6 \\
- Normal & 0 & 1 \\
- Overweight & 0 & 1 \\
- Obese & 0 & \\
\hline
\end{tabular}

Table 1. Characteristics of subjects and control group Mann-Whitney test)

Disclosure: The authors have no financial interest to disclose. 


\section{RESULT}

The subjects and control groups consist of 10 boys and 4 girls. The median age of each population are 9 years for subject group (range 8 years - 10 years) and 11 years for control group (range 9 years-14 years). The nutritional status is described in table 4.1. All of the subjects (The Non Denuded Palatoplasty) group were underweight but more than half of the control (The Conventional Two Flap Palatoplasty) group weights normally. (Table 1).
We conducted the cephalometric analysis by placing a transparent acetate sheet over the radiographs and the anatomical structures were outlined. We identify reference point and calculate the SNA, SNB, ANB, ANS-PNS (in centimeters) of each group with the results presented in table 2 .

\begin{tabular}{|c|c|c|c|c|c|c|c|}
\hline $\mathbf{n}$ & Group & $\begin{array}{l}\text { Age } \\
(\mathrm{yr})\end{array}$ & Gender & $\begin{array}{c}\text { SN } \\
\text { A }\end{array}$ & $\begin{array}{c}\text { SN } \\
\text { B }\end{array}$ & $\begin{array}{c}\text { AN } \\
\text { B }\end{array}$ & $\begin{array}{l}\text { ANS- } \\
\text { PNS }\end{array}$ \\
\hline 1 & Denuded Palatoplasty & 9 & $\hat{o}$ & 85 & 75 & 10 & 4,6 \\
\hline 2 & Denuded Palatoplasty & 9 & $\hat{o}$ & 66 & 68 & -2 & 4 \\
\hline 3 & Denuded Palatoplasty & 8 & $\hat{\delta}$ & 72 & 76 & -1 & 4.1 \\
\hline 4 & Denuded Palatoplasty & 10 & $\hat{\delta}$ & 73 & 74 & -1 & 4,9 \\
\hline 5 & $\begin{array}{l}\text { Conventional Two Flap } \\
\text { Palatoplasty }\end{array}$ & 10 & $\hat{o}$ & 82 & 81 & 1 & 5,2 \\
\hline 6 & $\begin{array}{l}\text { Conventional Two Flap } \\
\text { Palatoplasty }\end{array}$ & 11 & $\hat{o}$ & 72 & 75 & -3 & 3,3 \\
\hline 7 & $\begin{array}{l}\text { Conventional Two Flap } \\
\text { Palatoplasty }\end{array}$ & 10 & 우 & 77 & 81 & -4 & 4,5 \\
\hline 8 & $\begin{array}{l}\text { Conventional Two Flap } \\
\text { Palatoplasty }\end{array}$ & 9 & $\hat{o}$ & 76 & 74 & 2 & 4,5 \\
\hline 9 & $\begin{array}{l}\text { Conventional Two Flap } \\
\text { Palatoplasty }\end{array}$ & 9 & $\hat{o}$ & 74 & 73 & 1 & 4,2 \\
\hline 10 & $\begin{array}{l}\text { Conventional Two Flap } \\
\text { Palatoplasty }\end{array}$ & 11 & 우 & 77 & 81 & -4 & 4,8 \\
\hline 11 & $\begin{array}{l}\text { Conventional Two Flap } \\
\text { Palatoplasty }\end{array}$ & 11 & 우 & 73 & 74 & -1 & 4,4 \\
\hline 12 & $\begin{array}{l}\text { Conventional Two Flap } \\
\text { Palatoplasty }\end{array}$ & 12 & $\hat{\delta}$ & 87 & 86 & 1 & 4,2 \\
\hline 13 & $\begin{array}{l}\text { Conventional Two Flap } \\
\text { Palatoplasty }\end{array}$ & 12 & $\hat{\delta}$ & 81 & 86 & -5 & 5 \\
\hline 14 & $\begin{array}{l}\text { Conventional Two Flap } \\
\text { Palatoplasty }\end{array}$ & 14 & 우 & 78 & 90 & -12 & 5,3 \\
\hline
\end{tabular}

Table 2. Age, gender and individual measurements (SNA,SNB,ANB and ANS-PNS) on cephalograms

\section{Cephalometric Evaluation}

\begin{tabular}{lcc|cc}
\hline & \multicolumn{2}{c}{ The Non Denuded Palatoplasty (subjects) } & \multicolumn{2}{c}{$\begin{array}{c}\text { The Conventional Two Flap Palatoplasty } \\
\text { (control) }\end{array}$} \\
\hline & Median & Range & Median & Range \\
SNA & 72,5 & $66-85$ & 77 & $72-87$ \\
SNB & 74,5 & $68-76$ & 81 & $73-90$ \\
ANB & -1 & $-2-10$ & -2 & $-12-1$ \\
\hline
\end{tabular}

Table 3. Cephalometric Results 
The median of cephalometric measurements of The Non Denuded Palatoplasty and The Conventional Two Flap Palatoplasty was described in Table 3. Maxillary prominence in subjects from The Non Denuded Palatoplasty group was lower by $4,5^{\circ}$ in comparison to the Conventional group (SNA $=72,5^{\circ}$ and $77^{\circ}$, respectively). While the SNB point which represent the horizontal position of the mandible relative to the cranial base from The Non Denuded Palatoplasty group showed also a lower point by almost $7^{\circ}\left(\mathrm{SNB}=74,5^{\circ}\right.$ and $\left.81^{\circ}\right)$. However, the ANB angle which measures the relative position of the maxilla to mandible was, in turn, higher by $1^{\circ}$ from The Non Denuded Palatoplasty groups (ANB $=-1^{\circ}$ ) in comparison to the Conventional group $\left(\mathrm{ANB}=-2^{\circ}\right)$.
The dental casts were collected and categorized. One plastic surgeon and two orthodontist scored the dental cast. The examiners were given a reference image of GOSLON score 1 to 5 as a guide to categorize the dental casts. The five groups reflect a range of dental arch relationships: (score $1=$ excellent growth to 5 = very poor growth). After the dental cast had been scored, we then classify them into three groups: Group 1 consists of GOSLON score 1 and 2 (Good Growth), Group 2 consisst of GOSLON score 3 (Satisfactory Growth), and Group 3 consists of GOSLON score 4 and 5 (Poor Growth). A photographic representation of the GOSLON groups is shown in Figure 1.

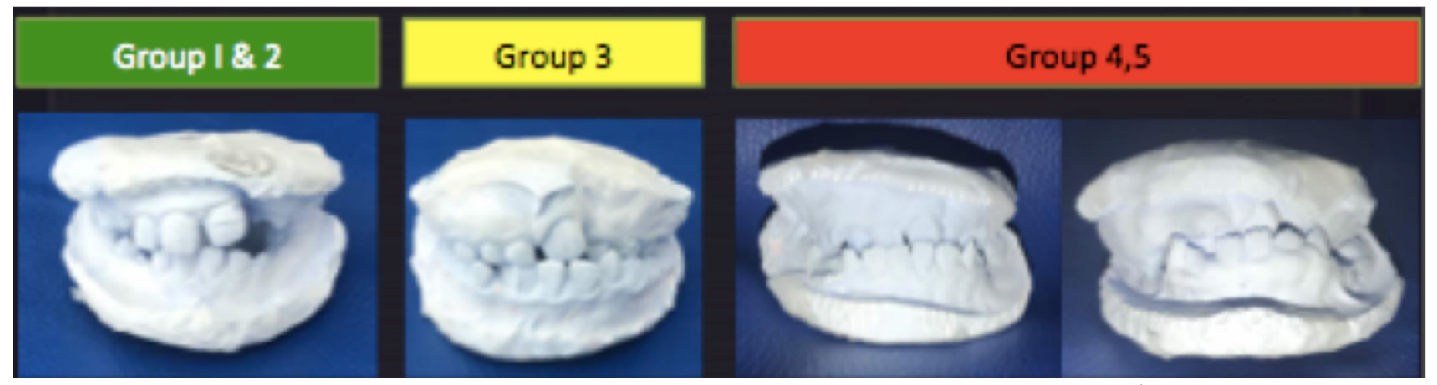

Figure 1. Dental cast grouping using GOSLON Yardstick method

The distribution of GOSLON Yardstick scores between each intervention is shown in Table 4 and Chart 1 presents proportion of each group.

\begin{tabular}{lcc}
\hline & $\begin{array}{c}\text { The non denuded } \\
\text { palatoplasty }\end{array}$ & $\begin{array}{c}\text { The conventional two flap } \\
\text { palatoplasty }(\mathbf{n}=\mathbf{1 0})\end{array}$ \\
\hline GOSLON Yardstick Type I & 0 & 0 \\
GOSLON Yardstick Type II & 0 & 1 \\
GOSLON Yardstick Type III & 2 & 3 \\
GOSLON Yardstick Type IV & 2 & 4 \\
GOSLON Yardstick Type V & 0 & 2 \\
\hline
\end{tabular}

Table 4. Distribution of GOSLON Yardstick scores between the two groups: The Non Denuded Palatoplasty and The Conventional Two Flap Palatoplasty 
In The Non Denuded Palatoplasty group, none of the patients demonstrated good growth (GOSLON scores 1 and 2), two revealed satisfactory growth (GOSLON score 3) and two had poor growth (GOSLON score 4 and 5). While in the Conventional Two Flap Palatoplasty group, one of the patients had good growth (GOSLON score 1 and 2), three displayed satisfactory growth (GOSLON score 3), while six had poor growth (GOSLON Score 4 and 5).
We analyzed the inter-ratter reliability of the GOSLON scores using intraclass correlation (ICC) test. The ICC test is used to asses the consistency, or conformity of measurements made by multiple observers measuring the same quantity. In this study, data are available for 3 raters on 14 subjects. The inter-rater reliability using ICC test were satisfying with the result 0.822 which is considered as good reliability, that is between 0.75 and 0.9 respectively. The ICC test will be described in table

5.

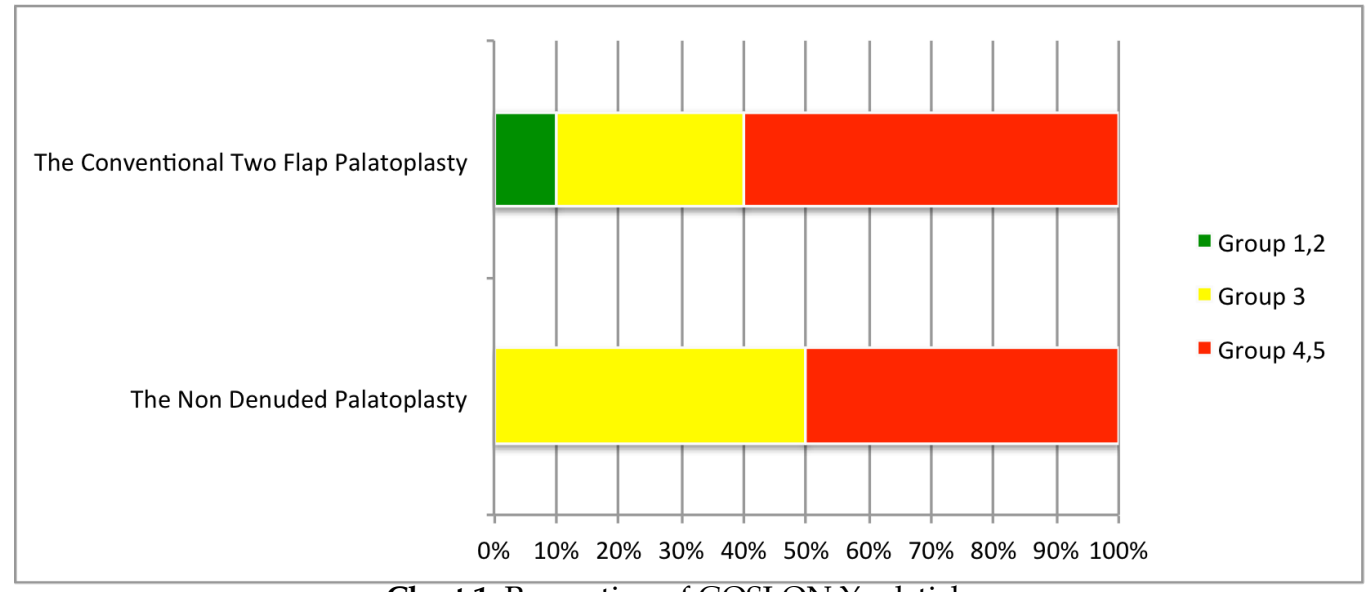

Chart 1. Proportion of GOSLON Yardstick

\section{Data Analysis of GOSLON Scores}

We analyzed the association between cephalometric variables (SNA, SNB, and ANB) which we suspected to be related to the GOSLON scores. According to Daskalogiannakis et al (15), GOSLON scores correlated weakly with both maxillary (SNA) and mandibular (SNB) cephalometric variables. For ANB, the authors found a negative correlation between it and the GOSLON scores(16).
However, the results of The Spearman test revealed that the variables are statistically insignificant $(p>0.05)$ which indicates that there are no correlation between GOSLON scores and all cephalometric variables (SNA, SNB, and ANB). The correlation between Cephalometric Variables with GOSLON Yardstick scores is depicted in Table 6.

\begin{tabular}{lccc} 
& Intraclass & \multicolumn{2}{c}{$\mathbf{9 5 \%}$ Confidence Interval } \\
\cline { 2 - 3 } Correlation & 0,606 & Lower Bound & Upper Bound \\
\hline Single Measures & 0,822 & 0,300 & 0,834 \\
Average Measures & 0,563 & 0,938 \\
\hline
\end{tabular}

Table 5. Intraclass Correlation Coefficient 


\section{DISCUSSION}

The influence of surgery on growth of the facial skeleton is an important factor in cleft surgery. Many authors reported the retardation of the growth of midface and maxilla following closure of palatal clefts, or cleft lip closure. Thus efforts should focus on to minimizing surgical trauma to reduce growth deficits, and enable good function. (17)

Comparison of two different surgical technique protocols in a single center offered an objective method in evaluating the efficacy of a particular technique. In this case control study, we evaluated the long term facial morphology by comparing The Non Denuded Palatoplasty Technique

\begin{tabular}{ccc}
\hline Variable & $\begin{array}{c}\text { Correlation } \\
\text { Coefficient }\end{array}$ & $\mathbf{P}$ \\
\hline GOSLON Score - SNA & 0,06 & 0,83 \\
GOSLON Score - SNB & 0,05 & 0,86 \\
GOSLON Score - ANB & $-0,11$ & 0,97 \\
\hline
\end{tabular}

Table 6. Correlation between Cephalometrics Variables (SNA, SNB, and ANB) with GOSLON Scores

versus The Conventional Two Flap Palatoplasty in the treatment of complete unilateral cleft lip and palate. To date, dental arch relationship for measuring growth outcomes through cephalometry and dental cast have been considered as the most useful tools to asses outcomes in the management of children with cleft lip and palate. Our findings suggest that technique modification does not affect the growth of the facial skeleton.

SNA angle proportion in The Non Denuded Palatoplasty group (median $=72,5^{\circ}$ ) is lower compared to the Conventional Two Flap Palatoplasty (control) group (median $=77^{\circ}$ ), however both groups are categorized as deficient or retrognathic maxilla (normal $79-85^{\circ}$ ). These findings indicate that there is no difference of maxillary growth between the two groups.

SNB angle proportion in The Non Denuded Palatoplasty group (median $=74,5^{\circ}$ ) is lower than the control group $\left(\right.$ median $\left.=81^{\circ}\right)$. This may suggest that the Conventional Two Flap Palatoplasty are superior to The Non Denuded Palatoplasty (normal $79^{\circ} \pm 3^{\circ}$ ).

Higher SNA and SNB angle seen in the control may be partially explained by the age difference between the groups. The Conventional Two Flap Palatoplasty group were on average older compared to The Non Denuded Palatoplasty hence have had more maxillary and mandibular growth.

Meanwhile, the ANB angle in The Non Denuded Palatoplasty group (median $=-1^{\circ}$ ) is higher compared to the Two Flap Palatoplasty (median $=-2^{\circ}$ ). This signifies that the maxilla was considerably more prominent in The Non Denuded Palatoplasty.
A more prominent maxilla observed in The Non Denuded Palatoplasty group may be caused by the age difference between the two groups. As the patient ages, it may be suggested that the maxillary growth falls behind the mandible, which in turn may result in negative ANB angle.

Nevertheless, both groups fall into the Class III skeletal jaw relationship category that being deficient maxilla or prognathic mandible (normal $1^{\circ}$ $\left.5^{\circ}\right)$.

Our results are comparable the findings of Fudalej et al (2012). Fudalej et al. evaluated dental arch relationship where the Exposed group was less favorable than in the Unexposed group (means 3.04 and 2.63). In the Unexposed group, in which they used an extended vomer flap ensured a tight closure of soft tissues without leaving a denuded surface area on the palate, revealed a better dental arch relationship.(18)

No case from The Non Denuded Palatoplasty had a GOSLON score 1 and 2, which signifies that the patients had an unfavorable treatment outcome that required extensive orthodontic treatment or combined surgicalorthodontic approach. Meanwhile The Conventional Two Flap Palatoplasty resulted in various GOSLON scores. This shows that the patient required treatment that varies from simple orthodontic treatment until combined orthodontic and orthognatic surgery treatments. 
This study has several limitations that may contribute to our result. There was severe attrition in the sample size over the length of the study. Only $20 \%$ patients of the initial study done

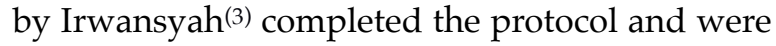
available for evaluation. One sample was excluded from our study as the patient had a bilateral complete cleft lip and palate, one sample refused to participate in this study, while others were unable to be contacted.

The age of evaluation (7-10 years) for maxillary growth were not representative of the final outcome. The main sagittal growth of the maxilla occurs after second dentition and through puberty. Therefore, further follow up maxillary growth evaluation after completion of growth is necessary ${ }^{(19)}$.

\section{CONCLUSION}

During craniofacial growth, patients with complete unilateral and bilateral cleft lip, alveolus and palate experience specific growth inhibition of the maxilla following completion of primary surgery. Therefore, the surgeon was eager to seek the best technique and operation timing with the intent of minimizing the repair's impact on maxillary growth.

Neither The Conventional Two Flap Palatoplasty Technique nor The Non Denuded Palatoplasty Technique resulted in good maxillary growth. Both techniques were thought to affect in disrupting anteroposterior, vertical and transversal growth.

As this research is a long term observation, final evaluation should wait until the patients reach 15 - 17 years old when maxillary bone ceases growing.

Further study that explores more aspect in terms of timing of repair and maxillary growth is needed. Numerous studies have been established. Delayed hard palate closure as shown by Gothenburg technique is one of the alternatives that is thought to yield better maxillary growth ${ }^{(20)}$.

\section{Corresponding author :}

Prasetyanugraheni Kreshanti, M.D.

Cleft Craniofacial Center. Plastic Surgery Division Cipto Mangunkusumo General National Hospital Pras_MD@yahoo.com

\section{REFERENCES}

1. Bishara SE, Krause CJ, Olin WH. Facial and Dental Relationships of Individuals with Unoperated Clefts of the Lip and/or Palate.pdf. Cleft Palate J. 1976;13:238-52.

2. Mars M, Plint D a, Houston WJ, Bergland O, Semb G. The Goslon Yardstick: a new system of assessing dental arch relationships in children with unilateral clefts of the lip and palate. Cleft Palate J. 1987;24(4):314-22.

3. Irwansyah D, Kristaninta B, Gentur S. The non denuded mucoperiosteal palatoplasty in precipitation healing process of palatal lateral deffect. J Plast Rekonst. 2012;1(3):323-326

4. Yoshida H, Nakamura A, Michi K, Wang GM, Liu K, Qiu WL. Cephalometric analysis of maxillofacial morphology in unoperated cleft palate patients. [Internet]. The Cleft palate-craniofacial journal: official publication of the American Cleft PalateCraniofacial Association.1992.p.419-24. Available from: http://www.ncbi.nlm.nih.gov/pubmed/1472520

5. Hoffman WY. Cleft palate. In: Plastic Surgery [Internet]. Third Edit. Elsevier Inc.; 2013. p. 568.e1583.e4. Available from: http://dx.doi.org/10.1016/ B978-1-4377-1733-4.00325-6

6. Monasterio F, Serrano A, Barrera G. A Study of Untreated Adult Cleft Palate Patients.pdf. Plast Reconstr Surg. 1966;38(1):36-41.

7. Taub PJ, Buchman SR, Patel PK, Cohen MN. Ferraro's fundamentals of maxillofacial surgery. second. Ferraro's Fundamentals of Maxillofacial Surgery. London: springer; 2015. 1-510 p. 
8. Eppley BL. Surgical Cephalometrics: Applications. Plast Reconstr Surg. 2007;120:92-104.

9. Sisco M kryger Z. Practical Plastic Surgery. Texas: Landes Bioscience; 2007.

10. Choudhary S, Cadier MAM, Shinn DL, Shekhar K, McDowall RAW. Effect of Veau-Wardill-Kilner type of cleft palate repair on long-term midfacial growth. Plast Reconstr Surg. 2003;111(2):576-82; discussion 583-5.

11. S.Georgiade G. Plastic, Maxillofacial and Reconstructive Surgery. third edit. S.Georgiade, Gregory. Riefkohl, Ronald. Levin L. S, editor. Williams \& Wilkins.

12. Dogan S, Olmez S, Semb G. Comparative Assessment of Dental Arch Relationships Using Goslon Yardstick in Patients With Unilateral Complete Cleft Lip and Palate Using Dental Casts, Two-Dimensional Photos, and Three-Dimensional Images. Cleft Palate-Craniofacial J [Internet]. 2012;49(3):347-51. Available from: http:// www.cpcjournal.org/doi/abs/10.1597/10-269.

13. Nollet PJ, Katsaros C, Van't Hof MA, KuijpersJagtman AM. Treatment outcome in unilateral cleft lip and palate evaluated with the GOSLON yardstick: a meta-analysis of 1236 patients. Plast Reconstr Surg. 2005;116(5):1255-62.

14. Hathorn I, Roberts-Harry D, Mars M. The Goslon yardstick applied to a consecutive series of patients with unilateral clefts of the lip and palate. [Internet]. The Cleft palate-craniofacial journal: official publication of the American Cleft PalateCraniofacial Association. 1996. p. 494-6. Available from: http://www.ncbi.nlm.nih.gov/pubmed/ 8939375.

15. Daskalogiannakis J, Mercado A, Russell K, Hathaway R, Dugas G, Long RE, et al. The americleft study: An inter-center study of treatment outcomes for patients with unilateral cleft lip and palate part 3. Analysis of craniofacial form. Cleft Palate-Craniofacial J. 2011;48(3):252-8.

16. Fudalej PS, Wegrodzka E, Semb G, HortisDzierzbicka M. One-stage (Warsaw) and two-stage (Oslo) repair of unilateral cleft lip and palate: Craniofacial outcomes. J Cranio-Maxillofacial Surg [Internet]. Elsevier Ltd; 2015;43(7):1224-31. Available from: http://dx.doi.org/10.1016/ j.jcms.2015.04.027
17. Gaggl A, Schultes G, Feichtinger M, Santler G, Mossböck R, Kärcher H. Differences in cephalometric and occlusal outcome of cleft palate patients regarding different surgical techniques. J Cranio-Maxillofacial Surg. 2003;31(1):20-6.

18. Dudkiewicz Z, Fudalej P, Kuijpers M, Offert B, Katsaros C, Piwowar W, et al. Dental Arch Relationships following Palatoplasty for Cleft Lip and Palate Repair. J Dent Res. 2011;91(1):47-51.

19. Ganesh P, Murthy J, Ulaghanathan N, Savitha VH. A randomized controlled trial comparing two techniques for unilateral cleft lip and palate: Growth and speech outcomes during mixed dentition. J Cranio-Maxillofacial Surg [Internet]. Elsevier Ltd; 2015;43(6):790-5. Available from: http://dx.doi.org/ 10.1016/j.jcms.2015.03.033.

20. Bakri S, Rizell S, Lilja J, Mark H. Vertical Maxillary Growth after Two Different Surgical Protocols in Unilateral Cleft Lip and Palate Patients. Cleft PalateCraniofacial Journal [Internet]. 2014;51(6):645-50. 
